ARTICLE

\title{
A window to teachers' ICT practices: Discerning between teaching and the complex science of pedagogy
}

Thirusellvan Vandeyar a

\section{Abstract}

Utilising Loughran's notion of the complexity of teaching, this study set out to explore how teachers used information and communication technology (ICT) in their classroom practices. The study is grounded in qualitative research methods. Data capture included a mix of semi-structured interviews, observations and document analysis. Data was analysed using content analysis methods. Findings were fourfold. First, small pockets of innovative teachers changed their pedagogy. Second, teachers' beliefs suggest (mis)understandings about their ICT induced teaching, which they perceived as changed pedagogy, but actually only their mode of curriculum delivery changed. Third, most teachers seemed to reposition their practice using technology to facilitate the demands of a scripted curriculum, thus merely changing their teaching practice. Fourth, teachers' apprenticeship of observation is further perpetuated through pre-service training that does not promote pedagogical experiential change.

Keywords: ICT. Pedagogy. Teaching. Experiential learning. Change agents.

\section{Introduction and background context}

The daily onslaught and social pervasiveness of information and communication technology (ICT) on our lives is not easy to avoid. The use of technology has influenced how we work, communicate, trade, manage finances, and keep abreast of the ever growing complexity of maintaining social networks. Yet, however rapid the effective exploitation of technology is in the different fields of human activity, the effective uptake of ICT in Education still needs to occur. As teachers, we always seem to lag behind other technology frontrunners, even though ICT offers significant affordances to radically change both teaching and learning. Given that ICT will eventually make its way into all classrooms, teachers must

a University of Pretoria, Pretoria, Gauteng, South Africa. 
become moral and purposeful change agents in order to engage in the "continuous renewal, and change expectations" that are ubiquitously presented by technology (FULLAN, 1993, p. 3).

Within the South African context initiatives to integrate ICT into Education did not begin with the 2004 e-Education policy. In fact, this policy made its way onto the Education scene long after schools were already in the throes of computer integration (VANDEYAR, 2010). The overarching e-Education policy goal anticipated that every learner would be "ICT capable" to be "full participants in the global community by 2013" (SOUTH AFRICA, 2004, p. 10). This did not happen, and schools still lag behind this policy imperatives. The theoretical underpinning of the e-Education policy is based on the notion that using ICT teachers will transform their teaching practice, and that ICT will foster learner-centred learning. To meet this mandate, a supplementary policy for professional teacher training was developed named "Guidelines for Teacher Training and Professional Development in ICT" (SOUTH AFRICA, 2007). This policy sets out the ICT knowledge, skills, values and attitudes required by teachers to implement the curriculum effectively. This policy sought to support the e-Education policy and the implementation of relevant curriculum. Neither of these policies have achieved their desired targeted timeframes nor have they made significant inroads to transform schools (PADAYACHEE, 2017; VANDEYAR, 2015).

In response to policy imperatives, public schools in South Africa were equipped and re-equipped (through enormous expense) with desktop computers, dumb-terminals, lap-top and tablet initiatives, and more recently interactive whiteboards. South Africa's pre-occupation to supply schools with "the flavour of the day" technology and access to technology did not necessarily yield "transformative educational practices" (NG'AMBI; BOZALEK, 2013). In the government's noble attempt to chase technology as a moving target, it left teachers far behind.

Sadly, teachers remain disenchanted with technology and most teachers are using it as an "add-on" in their teaching repertoire (HARRISON et al., 2002). Given that teachers are uniquely and crucially positioned at the point where policy meets practice (VANDEYAR, 2015), it would bode well for policy implementation if the focus was on changing teachers' beliefs and attitudes, ICT skills and pedagogy in the form of sustained training intervention and support (OWSTON, 2007).

Are teachers using technology in their classrooms? What are teachers doing differently with their technology in classrooms? How has their instruction 
changed? Does the changed practices reflect evolving pedagogies? How do teachers perceive their ICT induced teaching practices?

Accordingly, this study asks, how does the use of ICT influence teachers' practices?

\section{Exploring the terrain}

A review of the voluminous literature revealed several ways to understand the underlying decision-making process teachers may adopt in using new technology in their practice. Macrinkiewicz and Welliver (1993) explicate the incongruity between advocacy for technology use and the actual use by teachers. Mere access to technology does not translate into changed teacher practice or technology integration. The beliefs held by technology protagonist, teacher unions, academe and politicians are different from the disillusionment teachers have about educational technology, and thus teachers do not change their practice. According to McLaughlin (2005) this should be expected because the introduction of computers into the practice of teachers is very different to minor curriculum changes, and requires a significant shift in teachers' beliefs and attitudes. Even in cases when teachers are using technology we have to understand and question "what is meant by use?" Rieber and Welliver (1989) define "use" as the means of employing technology in teaching and describe a teacher's use of technology through five progressive stages namely: familiarisation, utilisation, integration, reorientation and evolution. Macrinkiewicz and Welliver (1993), also indicate that teachers use computer technology differently both before adoption (for example the time it takes to idea of computer use) and after adoption (the nature of their computer use).

Koehler and Mishra, acknowledge that teaching is a complicated scientific practice that requires the thoughtful process of "interweaving of many kinds of knowledge" (2009, p. 61). Teaching with technology brings about further complication to the classroom context as teachers are now expected to transcend their traditional pedagogical approaches in lieu of technology affordance. Significantly, the integration of ICT depends on the classroom context that advocates for teachers to have acquired content knowledge (subject matter), pedagogy knowledge (teaching strategies, learning theories, lesson planning and classroom management) and technology knowledge (ICT tools and resources). Although teachers may have these pre-requisite "knowledges", it is imperative and critical that they understand the inter-relationships between these knowledge constructs in order to successfully integrate ICT into their practice. The inter-relationships are defined as the 'knowledges' that are related to content pedagogy (teaching strategies of specific subject content), technology pedagogy (affordances of specific technology to enhance specific subject learning) and technology content (specific ICT to address specific subject-matter learning). These 'knowledges' define 
Mishra \& Koehler's TPACK model, which if integrated in the classroom context may yield good ICT induced teaching practices. The TPACK model has been used in various research studies as a 'fitness test' for the successful integration of technology into classroom practices (SOSA; MANZUOLI, 2019).

Davis (1989) presents a technology acceptance behavioural theory to explain the user's adoption of technology through two key constructs, namely perceived usefulness and ease of use. He suggests that a teacher's intention to use an innovation rests on his beliefs whether the new technology will enhance his teaching or work effectiveness. Furthermore, the teacher must believe that the innovation should be easy to use, thus not demanding much effort. Although Davis' theory is a well-established model to predict user acceptance and engagement with technology, it has been criticised for ignoring attitudes, individual choice and differences (YANG; YOO, 2003), predicting voluntary use of technology and not mandatory use (YOUSAFZAI et al., 2007), and for being simplistic.

Puentedura's (2009) describes teacher's use of technology through a process of transformation and enhancement. He describes teachers adoption of technology through the enhancement phase in which teachers may transform their teaching practice from using technology as a mere substitution tool (without any functional change) to augmentation (with functional improvement to their teaching practice). During the enhancement phase, teachers are using technology to working "better, faster \& more comprehensively" (KEARNEY et al., 2012, p. 91). Puentedura's transformation phase elicits teachers use of technology as a discernibly different practice, in which teachers modify, create and redefine their task, which would not be possible in the absence of relevant ICT. Puentedura's framework helps us to interrogate the level of teachers' technology integration in their classroom practice and may also help us to understand the digital opportunities and the roles of technology that the teachers design for their classroom practices. Teachers' level of technology integration may reflect on whether their pedagogy has changed or whether they are merely modifying their teaching with technologies (MARCOVITZ; JANISZEWSKI, 2015).

I argue that the affordances of ICT for teaching will only have an effect on classroom practices if there is careful and thoughtful lesson planning and design (FUJII, 2016). I use the notion of instructional design as a means of understanding and facilitating the complex nature of teaching (LOUGHRAN, 2013). Good teaching must be accompanied by good lesson planning and this is dependent on a number of salient criteria. First, that teaching involves a pre-lesson vision of how the lesson should unfold. Second, to achieve this vision of the anticipated lesson, thorough planning 
is key. Instructional-design theories are design-oriented focusing on enhancing learning through 'effective and efficient instruction', and being design-oriented makes it a theory directly useful to teachers, because it provides direct guidance on how to achieve their desired outcomes (CZERKAWSKI; SCHMIDT, 2018, p. 1). In this regard, design theories such as Gagne's Nine Events of learning (GAGNE, 1981), Analysis-Design-Development-Implementation-Evaluation - ADDIE (GAGNE et al., 2005) and other instructional design models provide essential design features to scaffold planning for effective teaching. The incorporation of design theory allows for the systematic design of computer assisted instruction (CAI), lesson planning, and preparation by defining outcomes, acknowledging relevant previous knowledge and experience of the learners, resources for the lesson, a pedagogy of approach, application of the subject matter, and reflection of the lesson. These essential features of design theory allow teachers to effectively plan, execute and reflect on their teaching practices to enhance good teaching with technology. However, the major gap in our knowledge for dramatic improvements in learning is how to help teachers to transform themselves from the standardized, industrial-age teaching and learning paradigm to a learner-centred $4^{\text {th }}$ industrial revolution paradigm of Education.

Central to the argument of ICT integration into classroom practices are teacher beliefs (GONZÁLEZ-SANMAMED; SANGRÀ; MUÑOZ-CARRIL, 2017; WANG; ERTMER; NEWBY, 2004). Ertmer describes first order changes for technology integration as being beyond teacher influence and being extrinsic to teachers' control. However, second-order barriers are intrinsic to teachers and include their beliefs about teaching, ICT, classroom practices, and willingness or unwillingness to change. Extrinsic factors may be addressed through the provision of resources and training opportunities, but second-order barriers require teachers to confront their beliefs, attitudes and existing practices.

Avidov-Unger and Magen-Nagar (2014), ) indicate that the main barriers to technology integration in teaching are teachers' attitudes and their inability to successfully infuse it into their professional repertoire. Positive perceptions (HERRERA; FERNANDEZ; SEGUE, 2018) and enhanced ICT skills seem to favour a more successful teacher ICT integrative practice. Convery (2009) affirms that ICT is an enabler to both teachers' practices and their professional identities. However, if teachers' professional calling is without agency or authority beyond the classroom, the use of ICT will occur as a form of "private practice" behind closed doors (RIEL; BECKER, 2000, p. 2).

The literature has established that ICT does influence both teaching (CHAI et al., 2014) and learning (HOWARD; CHAN; CAPUTI, 2015). The emergence of new 
technologies and the possibilities it presents to teaching and learning, also presents a range of new pedagogical issues in classrooms. Various questions arise about the integration of technology into classrooms and its influence on teaching and learning. Sharples et al. (2014, p. 24), found that teachers' practices are changing through experimentation with digital technology, thus enhancing their "digital scholarship". There is an expectation that teachers' exploration with ICT may yield teaching strategies that differ from their current anachronistic approaches.

However, research on ICT integration in schools reveal that though teachers are developing their own ICT integration skills, they still lean on their traditional teaching strategies (VANDEYAR, 2013). Thus, the enabling effect of ICT in the current classroom space is used to support traditional modes of teaching. Empirical studies suggest that technologically enhanced classrooms may bring with it new practices (HOWARD; MATON, 2011) but, whether these innovative practices are yielding renewed or enhanced pedagogical approaches remains to be explored. Furthermore, these creative applications of ICT use in classrooms may be viewed, by those not familiar with the science of teaching, as being transformational in the teaching and learning context. Accordingly, this study attempts to explore teachers' ICT integration practices and whether teachers perceive these practices as a resemblance of pedagogical change.

\section{Theoretical framework}

I borrow from Loughran (2013, p. 118) the notion of pedagogy as being "embedded in the relationship between teaching and learning" to underpin this study. In foregrounding this theoretical framework, I argue that pedagogy is the principal construct in teaching and learning, and thus the complex nature of pedagogy must not and should not be viewed as being synonymous with teaching which is viewed as the simple act of transmission of information. To discern between teaching and pedagogical practice the following argument is presented.

Loughran (2013) posits that pedagogy is an Education ideal that is conceptualised as being rich, complex and sophisticated. This notion of pedagogy is viewed as being integral to both teaching and learning, where teaching is intrinsically linked to learning and vice versa. The two constructs "teaching" and "learning" coexist in the paradigm of pedagogy. Loughran (2013) explicates pedagogy as being a complex process; first, pedagogy should be understood as being a "problematic" thinking process when teachers have to make informed decisions about their classroom practice. Second, pedagogical practice involves the negotiation of "multiple decision points" in the classroom context by both teacher and learner. Thus, pedagogy informs our teaching practice as being a process involving the 
professional judgement of teachers as active, reasoning decision-makers that guide the teaching-learning dynamic relationship (WEBB, 2014).

In contrast to the complex nature of a pedagogy that "embraces and essential dialogue between teaching and learning" is the uncomplicated notion of teaching (BEETHAM; SHARPE, 2007, p. 2). They describe the term "teaching" as negating the active nature that constitutes "learning", and by this extension denying a learner's capacity to learn. In this vein, teaching is defined as the simple process of delivering information, and the teacher is viewed as a mere conduit for the transmission of knowledge. This reduces teaching to the process of delivery of the subject matter, and learning involves the passive "absorption" of the information. The process of teaching is viewed as a set of "routines" in the delivery of curriculum content, without the consideration of whether "learning" is actually taking place (LOUGHRAN, 2013, p. 119). An important focus in this study is the notion of "pedagogy" and its implication for teaching and learning; the coexisting relationship in which "teaching influences learning" and by the same token "learning influences teaching" (LOUGHRAN, 2013, p. 36).

\section{Research method}

A broader study examined teachers' appropriation of the e-Education policy and the influence of this policy on teaching and learning in South African schools (VANDEYAR, 2015). The broader case study (SILVERMAN, 2006) approach attempted to understand teachers' experiences as they respond to the national e-Education policy in their classroom practice. Data garnered from the larger study were ripe for this sub-analysis focus on teachers' ICT induced classroom practices.

Using maximum variation sampling, schools were purposefully selected to classroom practices in socio-culturally diverse settings (GLESNE, 2006). A qualitative research design was best suited to accurately represent the constructed realities of the participants as they perceived it to be (CRESWELL, 2009). The data reported in this paper were garnered from interviews, observations, field notes and document analysis (SILVERMAN, 2006). To triangulate data obtained from teachers' classroom observations, teachers were interviewed (STAKE, 2005) and document reviews (lesson plans, learners' books, screen shots, websites and classroom décor) were garnered (DENZIN; LINCOLN, 2005). A researcher journal was used to record field notes and personal reflections at all research sites (GLESNE, 2006).

Findings from the broader study revealed four important and pertinent issues: First, the e-Education policy was not communicated to all schools in this study. Second, the integration of ICT was not driven by the e-Education policy mandates, 
but rather by teachers' beliefs and attitudes. Third, the lack of systemic support from districts and province catalysed communities of practice between schools. Fourth, there was a lack of systemic coherence between the district's curriculum and e-learning units (VANDEYAR, 2013, 2015).

Subsequent to the above findings, data was re-coded specifically for teacher's perceptions of their ICT practices (CHARMAZ, 2005) and to capture nuances of teacher's changed practices in their use of ICT. In this regard, the findings were mined for two principal priori themes namely: changed teaching practices and changed pedagogical practice. Using a methodology of portraiture I (re)searched for "goodness" in the ICT practices of teachers (LIGHTFOOT, 1986). This study reports on the teaching practices of six teachers that participated in the broader project, across various school context, subject disciplines and school grades (see Table 1 and Table 2). Research participants were purposefully selected because they were identified as teachers that were voluntarily using ICT in their teaching practice. These teachers were identified as agents of change through inception interviews with the principals of the respective schools.

Table 1 - Rubric of teacher demographics and practices

\begin{tabular}{|c|c|c|c|c|c|}
\hline Teacher & $\begin{array}{l}\text { School, grades and } \\
\text { subjects }\end{array}$ & $\begin{array}{c}\text { Teaching } \\
\text { experience }\end{array}$ & $\begin{array}{l}\text { ICT training and } \\
\text { experience in } \\
\text { ICT teaching }\end{array}$ & $\begin{array}{l}\text { Technology } \\
\text { use }\end{array}$ & $\begin{array}{l}\text { Changed } \\
\text { teaching or } \\
\text { pedagogy? }\end{array}$ \\
\hline Shenel & $\begin{array}{c}\text { Public Primary School: } \\
\text { Foundation phase } \\
\text { Grade } 2\end{array}$ & 21 years & $\begin{array}{l}\text { Self-taught } \\
5 \text { years }\end{array}$ & $\begin{array}{l}\text { Data projector, } \\
\text { Teacher laptop } \\
\text { and Smart } \\
\text { phone }\end{array}$ & Teaching \\
\hline Botha & $\begin{array}{l}\text { Public Secondary } \\
\text { School: } \\
\text { Mathematics Grade } 12\end{array}$ & 24 years & $\begin{array}{l}\text { Self-taught } \\
4 \text { years }\end{array}$ & $\begin{array}{l}\text { Data projector, } \\
\text { Teacher laptop, } \\
\text { Visualiser, iPad }\end{array}$ & Teaching \\
\hline John & $\begin{array}{l}\text { Public Primary } \\
\text { School: } \\
\text { Natural Science } \\
\text { Grade } 7\end{array}$ & 27 Years & $\begin{array}{l}\text { Corporate } \\
\text { experience \& } \\
\text { Self-taught } \\
5 \text { years }\end{array}$ & $\begin{array}{l}\text { Data projector, } \\
\text { Teacher laptop } \\
\text { Interactive } \\
\text { White Board, }\end{array}$ & Teaching \\
\hline Stefan & $\begin{array}{l}\text { Public Secondary } \\
\text { School: } \\
\text { Mathematics } \\
\text { Grade } 9\end{array}$ & 4 Year & $\begin{array}{l}\text { Undergraduate } \\
\text { experience } \\
3 \text { years }\end{array}$ & $\begin{array}{l}\text { Data Projector. } \\
\text { Smart phone, } \\
\text { Web-site }\end{array}$ & Teaching \\
\hline Roux & $\begin{array}{l}\text { Public Primary } \\
\text { School: } \\
\text { Grade } 7\end{array}$ & 7 years & $\begin{array}{l}\text { Undergraduate } \\
\text { experience and } \\
\text { Self-taught } \\
6 \text { years }\end{array}$ & $\begin{array}{l}\text { Laptop, data } \\
\text { projector, } \\
\text { Video cameras }\end{array}$ & Pedagogy \\
\hline Rudolf & $\begin{array}{c}\text { Independent } \\
\text { comprehensive } \\
\text { School } \\
\text { Grade } 7\end{array}$ & 20 years & $\begin{array}{l}\text { Corporate } \\
\text { experience \& } \\
\text { Self-taught } \\
6 \text { years }\end{array}$ & $\begin{array}{l}\text { Data projector, } \\
\text { Web-site, } \\
\text { Desktop } \\
\text { computers }\end{array}$ & Pedagogy \\
\hline
\end{tabular}

Source: Own elaboration (2020) 
Table 2 - Demographics of school research sites

\begin{tabular}{lcccc}
\hline Schools type & $\begin{array}{c}\text { Socio-economic } \\
\text { category }\end{array}$ & $\begin{array}{c}\text { Number of } \\
\text { schools }\end{array}$ & Teachers & $\begin{array}{c}\text { Total } \\
\text { observation } \\
\text { hours }\end{array}$ \\
\hline Public primary- urban & $\begin{array}{c}\text { Underprivileged } \\
\text { Privileged }\end{array}$ & 1 & 1 & 3 \\
Public secondary- urban & Privileged & 2 & 2 & 6 \\
$\begin{array}{l}\text { Independent/Private } \\
\text { Comprehensive - urban }\end{array}$ & Privileged & 1 & 1 & 6 \\
\hline
\end{tabular}

Source: Own elaboration (2020)

\section{Findings}

\subsection{Changed teaching practices}

This theme represents teachers' innovative teaching strategies to deliver their lessons. In this instance I use Loughran's (2013) notion of teaching as an act of transmission of information as an inclusion criterion to encapsulate this theme. The categories of this theme emerged by virtue of the manner in which teachers used innovative means to deliver the curriculum. Evidence suggests that teachers used their traditional teaching styles but with the affordances of technology - thus the proverbial "new wine in old bottles". Various teaching nuances are described as participants' innovatively used ICT to change the manner in which they delivered the curriculum. Various changes induced by ICT in teachers' classroom practice included, using digital images as whiteboards, real-life learning experiences and post-classroom lessons for support.

\section{Theme 1: Working with digital images as whiteboards}

In this theme, I present two teachers who resorted to innovative ICT practices as indicated in two different scenarios. The first is that of Shenel (a grade one teacher) and the second is Botha's (a grade 12 mathematics teacher), both of whom created digital images of learner's workbooks to project onto a screen. This act of mirroring the exact workbook pages of their learners arose from the desire to teach smart and effectively. Creating exact digital replicas of learner's workbooks facilitated their lesson in the sense that it prevented learners enquiring "how many lines do I need to do that?" or "what is the scale of the drawing of the graph?", questions that usually occurred with the use of the chalkboard. Now that the teachers work surface was an exact projected image 
of the learners' workbook, teachers felt that they eliminated this problem. Significantly though, this changed practice played out in two extremely different contexts namely, at a foundation phase (grade 1) and at a senior phase (grade 12) respectively. Although the technology used was different, the teaching practice was the same.

In Shenel's lesson, she used a digital copy of the learner's writing workbook to demonstrate to learners how to write cursively. She claimed, "it is so important for learners to see my hand movement as I form the letters of the words on the whiteboard" (See Figure 1). Shenel created different digital images of the learner's workbook pages (See Figure 2), and stored these images in separate files on her desktop for quick access. She used this teaching strategy to effectively make the transition from double spaced lines to single spaced lines. In this way, she had access to different digital page line formats to make the transition from broad lines to narrow ones. She used her smart phone to create the digital copies by mounting her phone on a laboratory 'retort' stand (used as a camera stand), and then used a data projector to project the digital pages onto her whiteboard. In this way, she wrote on the whiteboard illustrating to her grade one learners exactly the way her hand moved to develop their cursive writing skills.

Figure 1 - Image of learner's book

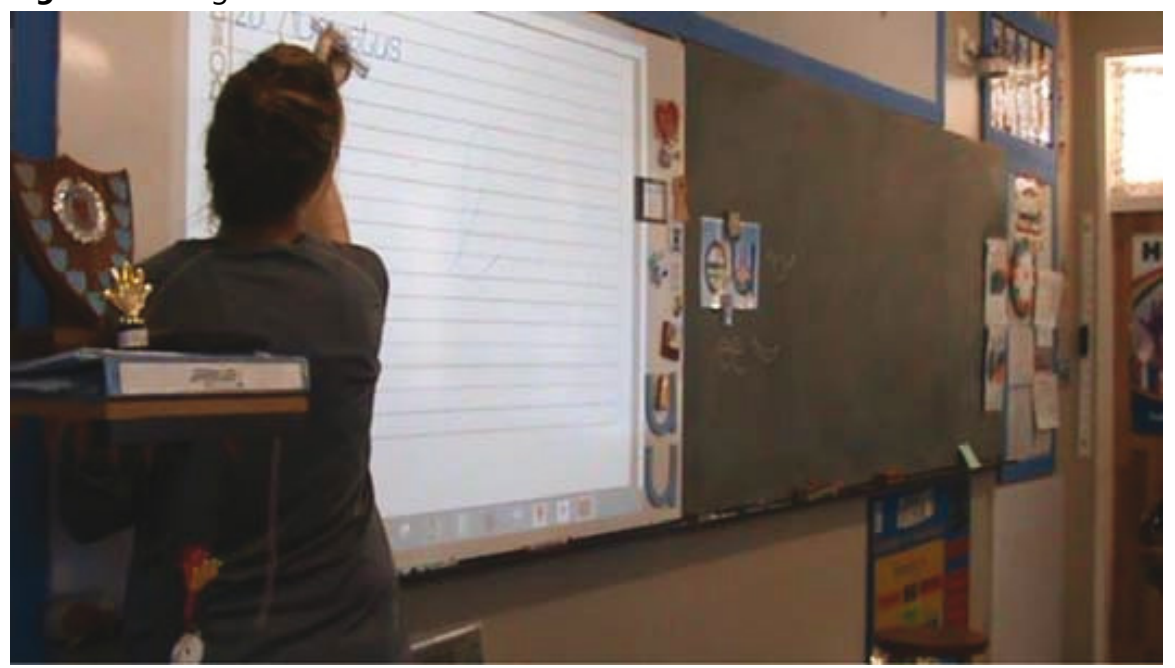

Source: Own elaboration (2020) 
Figure 2 - Various formats on desktop

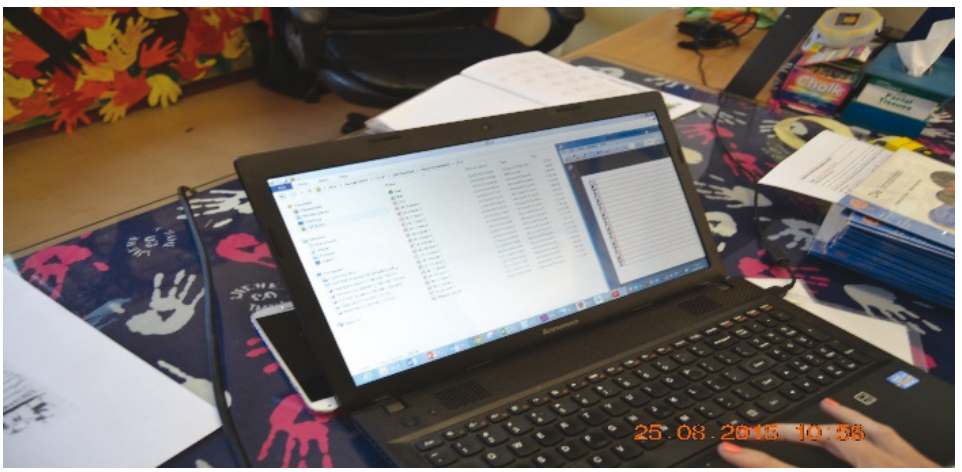

Source: Own elaboration (2020)

Shenel explained that the advantage in this approach was that she could make the shift from "double" spaced lines to "single spaced" lines, which she claimed allowed the learners to more easily make the transition. She found that in the traditional approach of using the chalkboard, she would have to individually support many learners, and this has been reduced significantly by the use of technology. Furthermore, she also learnt how to position herself unobtrusively with respect to the whiteboard and the data projector as she wrote on the digital image.

As a further adaptation to her teaching practice, Shenel would often project exact digital images of learners' workbook onto the whiteboard to facilitate her teaching. This allowed her to illustrate to learners the solutions to the exercises, exactly as it appears in their textbooks/workbooks.

Figure 3 - Teachers digital copy of workbook

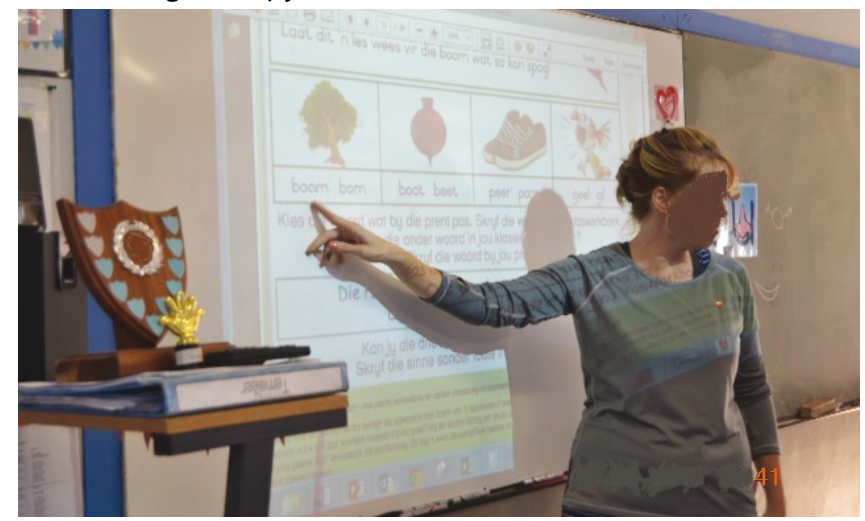

Source: Own elaboration (2020) 
Figure 4 - Learners workbook

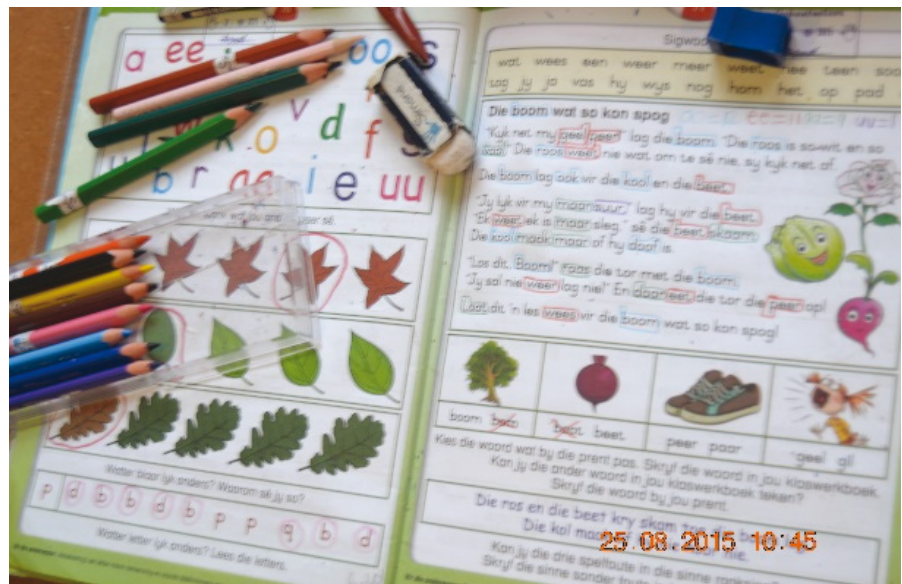

Source: Own elaboration (2020)

In response to this teacher's perceptions of how ICT changed her practice, she indicated:

I think it's important because we living in a world where ICT is more important. So teachers also got to stay up with the modern technology you can't still use the old methods The children are really going to find it boring if there so much things out there.

Botha, a secondary school teacher also applied a similar teaching technique although using a different set of technology tools. In this scenario, this grade twelve mathematics teacher used technology to change her teaching style. In teaching the section on graphs (trigonometric or algebraic functions), she felt that the use of the traditional chalkboard had limitations and resulted in a loss of teaching time, because her free hand graphical drawings invited numerous questions from learners, particularly with respect to scale of drawings. Using a Visualiser (see Figure 5) as a technology tool to project and work on an exact copy of the learner's workbook page, she could draw graphs and this did not invite learner query on the issue of scale of drawings.

Botha believed that the use of technology offered additional teaching value to her. She elaborated on the benefits of teaching with the Visualiser as new technology: "You are 'facing' your learners whilst teaching, as opposed to having your back to the learners as in the case of the traditional chalkboard use. This feature allows you to have more control and discipline over your classroom teaching". 
Figure 5 - Botha's use of the Visualiser

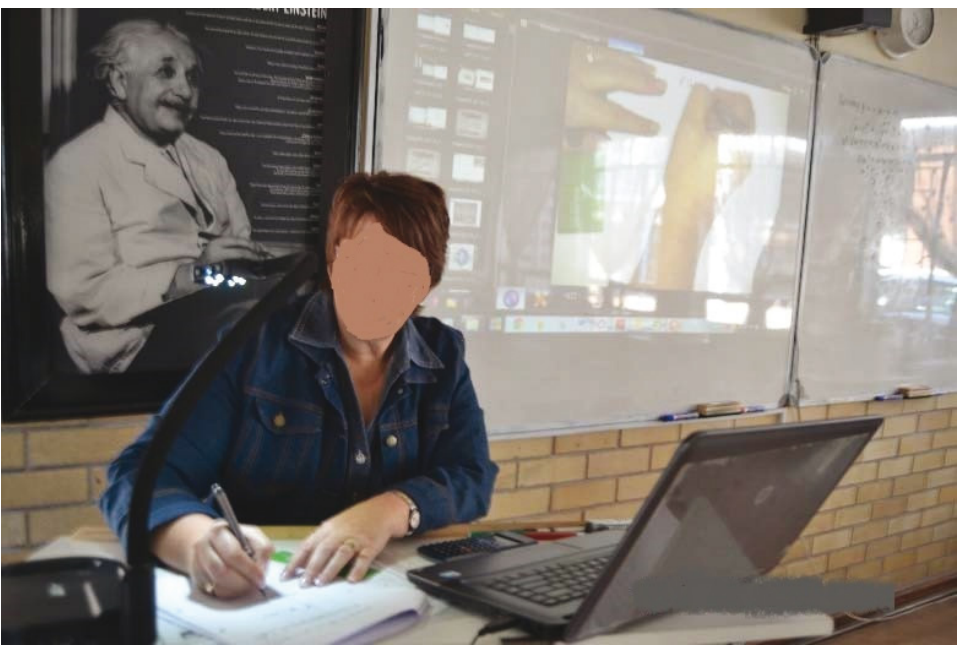

Source: Own elaboration (2020)

Botha used technology in innovative ways. She enjoys exploring with new technology and had a smorgasbord of different technologies in her classroom. She also indicated how the use of the Visualiser was used to record her lesson in order to support learners who may be absent from her current lesson. Botha responds to the question of how her teaching practice has changed. "So it will be good for us to capture those learners that can easily fall behind because some us are old methods are boring, non-stimulating and all that. It is good to stay abreast with different tools that society is using. Does it make sense?"

\section{Theme 2: Experiential learning}

This theme emerged from observing a grade six natural science teacher's use of technology to expose learners to real-life contexts. This classroom's context is set in a very low socio-economic township school.

John, a natural science teacher seemed to be focused on the ICT affordance of catering for different learning styles. He was adamant that the visual and auditory affordances that ICT bring to the classroom enhances his teaching and learning. In the observed science lesson, he demonstrated the design and functioning of the 'motor'. He also allowed learners to use the interactive whiteboard to design electronic circuits. To facilitate his teaching, he used a learner to control the 
desktop computer whilst he explained to the class (see Figure 6). He describes the benefits of using ICT in his classroom: "But the greatest advantage of ICT is that learners must experience the real world in the class. The class mustn't be a place where it is 'kunsmatig' [meaning artificial] you know... artificial, the classroom must be made as real as possible".

In responding specifically to how his ICT teaching practice changed with the use of technology, he said: "Well the fundamentals remain the same I would say... you move from the known to the unknown. From big to small, dynamic movement for you as a teacher. The fundamentals remain. But funny enough but you can only get to that stage, when you are equipped with ICT".

Figure 6 - John's use of an interactive whiteboard

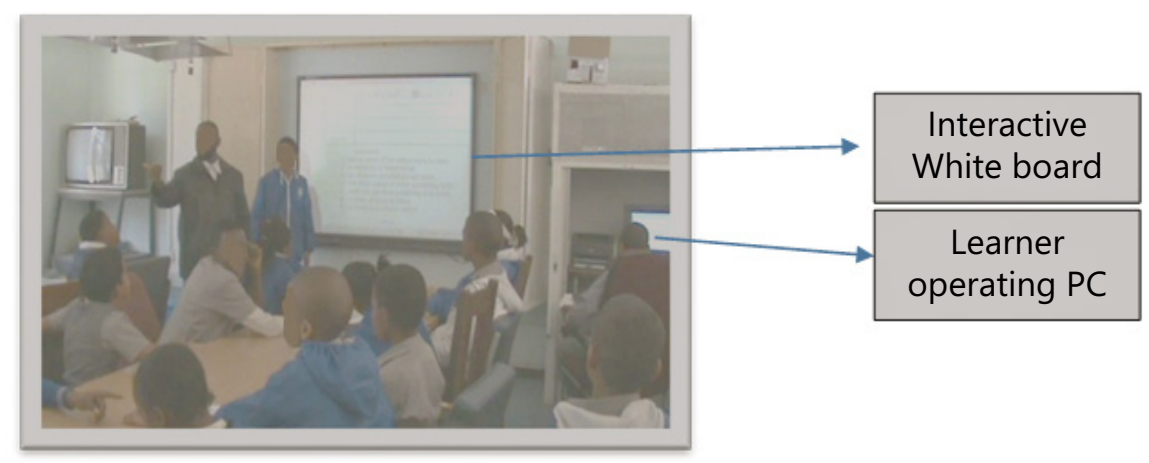

Source: Own elaboration (2020)

\section{Theme 3: Using technology for lesson revision}

In this theme, observation of teachers practice revealed that ICT is used for the purpose of post-lesson support or assessment feedback. Both participants presented here are that of mathematics teachers' practices. In the first instance, Jolandi recorded digital images of learners' "high frequency errors" as she was in the throes of assessing their work. In the second vignette, Stefan made video recordings of some mathematic lessons for after-school support.

Jolandi, a grade twelve mathematics teacher used her iPad to capture images of typical errors that were made by her learners. During her assessment of learners' task (See Figure 4), she would identify high frequency errors of learner's mathematical 
misconceptions. The following day she would display the images to the class for discussion. She indicated that this image of high frequency errors presented evidence that was 'worth a thousand words'. She relates her experience as follows:

While I am marking their test or assignments, I take camera shots of the exact errors made by the learner. I obviously do not reveal his or her name, except that I capture only the error digitally. In class, I display the error on screen, for class discussion, indicating that this is a high frequency error (made by many learners). Off-course, the students want to know whose paper it is, but now you got it there... it is what they have done.

Figure 7 - iPad used to capture high frequency errors

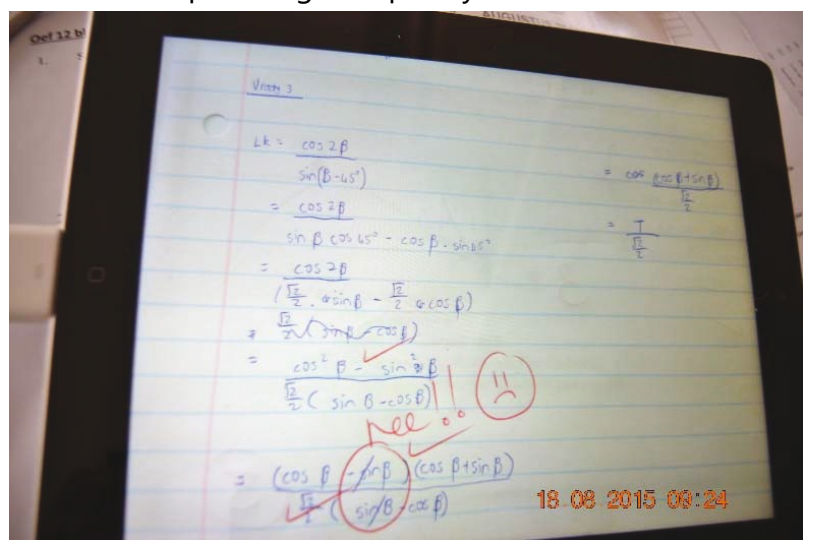

Source: Own elaboration (2020)

Jolandi's technology classroom included the use of a data projector, laptop, and an iPad. The significant change that ICT brings to Jolandi's teaching practice is that she found the iPad created an opportunity to teach smart. She would use the iPad as a portable chalkboard, and mirrored the iPad onto a screen for the entire class. In this way, she claimed that she changed her practice from calling learners to the chalkboard to sitting among the learners and letting them demonstrate to the class a particular math problem. Jolandi describes how the use of ICT changed her practice.

"It was firstly always felt I need to be more part of my class, I didn't like to turn my back to class while work on the whiteboard. I wanted to keep the kids 
involved, so I wanted something where I could 'keep them in eye' and be between them when I teach".

Stefan, a mathematics teacher, used a video camera mounted above his desk to record his short videos of his teaching a particular topic. He did this at home and then uploaded this video to his own personal website. He claims that though his website is ironically named as "ihatemath.co.za," it seemed to catch the attention of his learners and actually encourages the learning of mathematics. He claimed that these videos enhanced his teaching because learners had access to his website for after school support, if they needed to re-visit his lesson (see Figure 8). He demonstrates to learners how to scan the QR code to access the website videos from their smart phones (Figure 9).

Figure 8 - Stefan's website

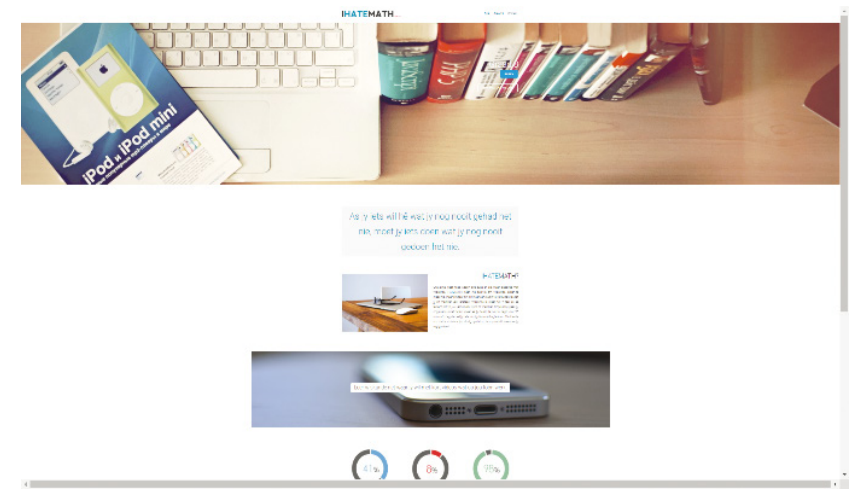

Source: Own elaboration (2020)

Figure 9 - Stefan demonstrating Smartphone access to his website

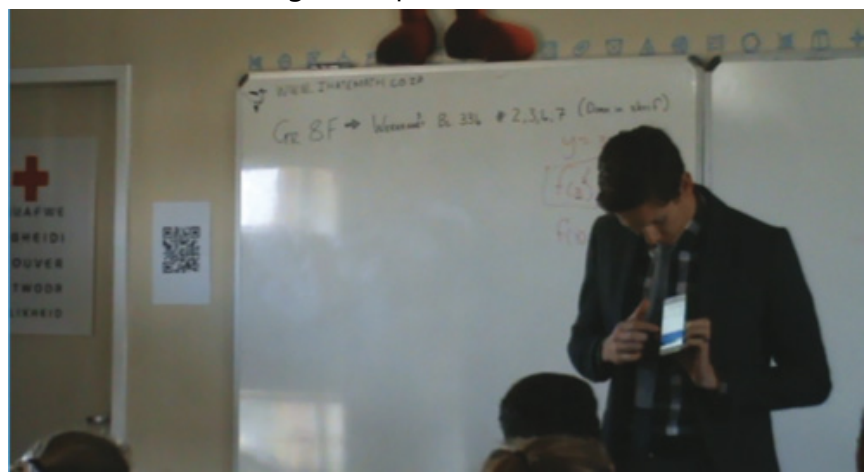

Source: Own elaboration (2020) 


\subsection{Changed pedagogical practices}

In this theme, I use Loughran's (2013) conception of pedagogy as a "relationship of teaching and learning" as an inclusive criterion. Using Loughran's definition of teaching, the two teachers described in this theme changed their teaching pedagogy. The pedagogical changes facilitated by ICT included a project-based learning and a problem-based learning approach respectively.

Roux, a senior primary natural science teacher, changed her pedagogy by effectively planning for both her teaching, and the context in which the learner learns. She used a constructivist approach by designing her lesson as a learnercentred activity. In this project-based lesson, her teaching strategy involved learners who had had to design and develop a video, and a presentation about an environmental issue (example river pollution). The teacher facilitated the use of technology to effectively plan the lesson as a project-based collaborative activity. The essence of observing this lesson was that learners were constructing their own knowledge through a project-based pedagogy (see Figures 10 and 11). It must be noted that this activity occurred after school hours and not during the normal teaching programme.

Figure 10 - Learners engaged in developing their projects

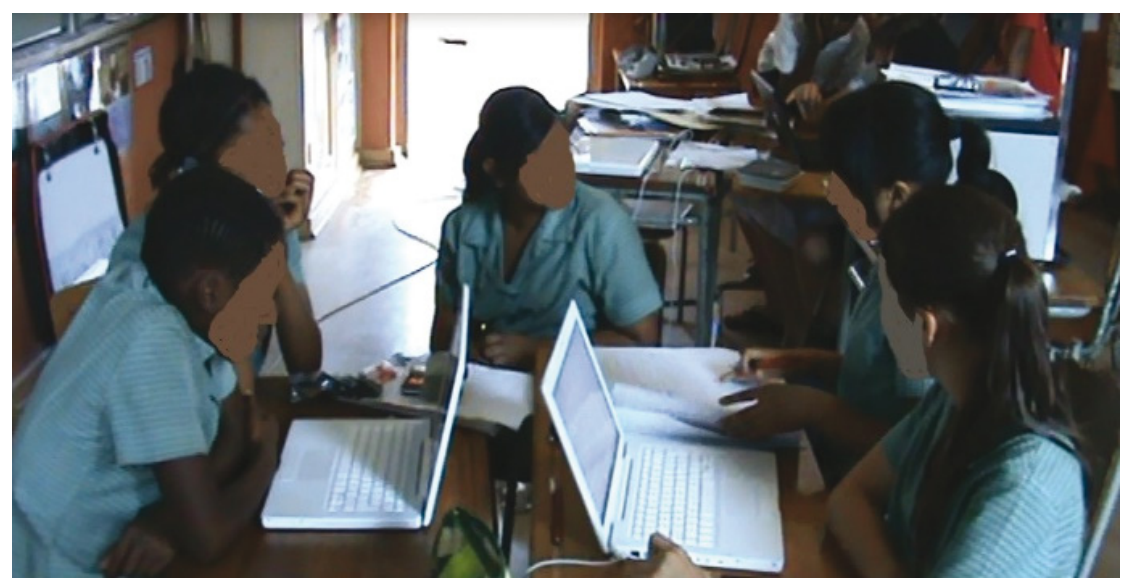

Source: Own elaboration (2020) 
Figure 11 - Learners engaged in developing their projects

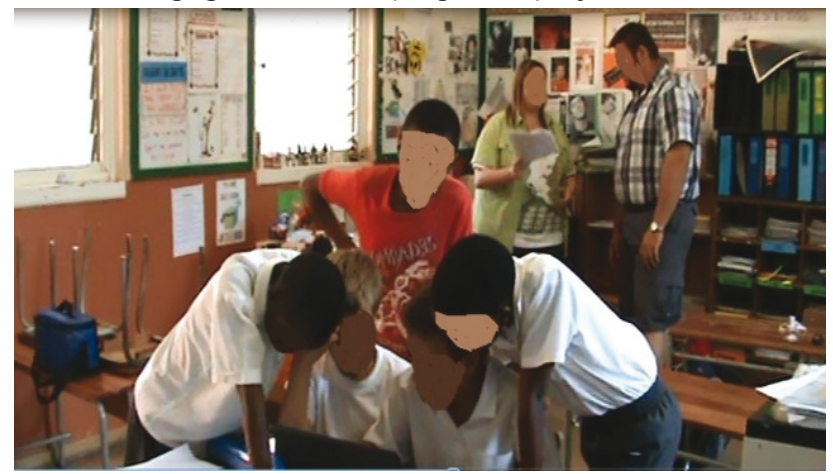

Source: Own elaboration (2020)

Rudolf, a language teacher used a problem-based teaching-learning approach. In this portrait, Rudolf used various forms of technology to plan his lesson for maximum learner engagement. In this lesson, learners had to conduct research by garnering data from family, friends and neighbours about their personal experiences related to various types of illnesses. Learners had to collate, analyse and present their findings to the class. Learners also had to access some additional information necessary via ICT tools for this activity from Rudolf's personal web-site, which included the problem brief, access to an online survey software (Monkey Survey) and some research websites. Learners already had an existing ICT skills base, which included knowledge of spreadsheets and presentation software. This was an individual activity, but learners had to construct their own knowledge about their findings (Figure 12). This lesson occurred within the scheduled subject period. The setting was in an independent school in which teachers have more freedom to deliver the curriculum in a manner that encourages innovative and creative teaching.

Figure 12 - Rudolf's class

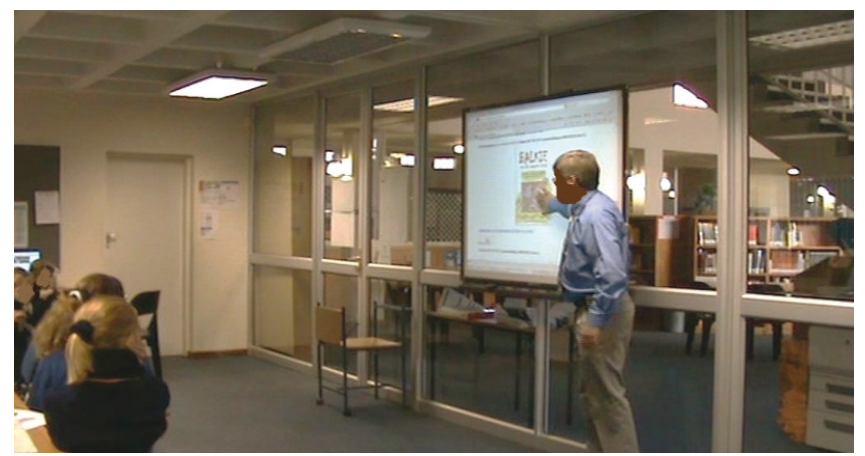

Source: Own elaboration (2020) 
Though teachers attributed various reasons as to why they used ICT in their classroom practice, there was no distinct indication why some changed their pedagogy while others changed their teaching. However, teachers in this study used ICT based on their own will, beliefs and attitudes and not imposed by any school management, district authority or e-Education policy mandate (VANDEYAR, 2015). Some reasons for making the shift to using ICT were: Rudolf believed that learners should be exposed to $21^{\text {st }}$ Century skills and be ready for a career beyond school that demands ICT competence. John believed that ICT offered unique opportunity for catering for different learning styles namely, visual and auditory learners. Jolandi believed that ICT offered her an opportunity to teach smart and in so doing could manage to survive the arduous teaching day "growing older, you realize I won't be able to swing from the chandeliers from 7- o'clock till to 2-o'clock every day." Roux indicated that by using ICT, she was able to communicate with her learners more easily, and found that learners were more attentive. Botha claimed that the use of technology allowed her have better classroom control and she needed to teach smarter.

\section{Discussion of findings}

Findings reveal a clear distinction between those teachers that changed their teaching practice and those that changed their pedagogy. While acknowledging most teachers' innovative use of technology to deliver the curriculum, their teaching was characterised by learners being passive onlookers. These teachers were unequivocal about how the use of technology changed their teaching strategy but responded in ways that describes the influence of technology on facilitating their teaching practice. Teachers seemed to adopt the new technology innovation for "ease of use" (DAVIS, 1989) in delivering of the curriculum and fell short on the "perceived usefulness" (DAVIS, 1989) of technology in influencing their pedagogy.

Clearly, teachers are exploring with new technology in unique ways and are adapting their classroom practice in an attempt to enhance their teaching. However, teachers that changed the way they delivered the curriculum using technology apparently did not actively engage their learners through the ICT mediated tools. This seems to suggest that the main focus of these teachers was on using ICT to enhance their teaching practice (curriculum delivery) without making any change to their teaching to include learner participation. As argued by Puentedura (2009), teachers merely changed technology without any significant change to their teaching pedagogy. Furthermore, they merely augmented or altered their presentations with slide transitions or animations (PUENTEDURA, 2009). This is aligned with what Puentedura terms 'enhancement stages', 
in which teachers merely improve the way they are delivering the curriculum. In the second instance, however, both teachers made a concerted shift in their teaching strategy to include a learner-centred approach with learners as active participants in their lessons. Their teaching changed from a traditional approach to constructivist pedagogy, which was embedded in the relationship between teaching and learning (LOUGHRAN, 2013).

In an attempt to understand why teachers that used technology to change their teaching practice believed that they changed their pedagogy, I argue as follows:

First, I examine this anomaly through teachers' existing beliefs about what constitutes pedagogical practice. A central thread that binds teachers' perceptions in this study is their belief that the use of ICT has changed their teaching pedagogy, though they merely creatively changed the way they delivered the curriculum. Teachers' espoused theory, what they say they are doing differently in their classrooms, is not in harmony with what actually transpires (theory-in-use) in their classrooms (ARGYRIS; SCHÖN, 1974). The evidence suggests that most teacher participants believed that their use of technology in their lessons was a change in their pedagogy. They seem to have a false understanding of what constitutes a changed pedagogy. It would seem that there are deeper underlying foundations that may support this apparent (mis)understanding. Teachers learn about teaching through the "apprenticeship of observation" (BORG, 2004, p. 274) that teaching is a simple task of transmission of subject content. Many teachers enter classrooms with a baggage of prior knowledge entrenched by at least twelve years of observing how their teachers' taught. This phenomenon may explain teachers' notions and preconceptions of what teaching is all about.

Second, and quintessentially, we have to agree that the integration of ICT in schools is a phenomenon that is uniquely different to minor changes in curriculum content, and is not simply a question of re-organising the knowledge base of educators but essentially getting "teachers to start from base zero" (FULLAN, 1992, p. 3). Although teachers may have these pre-requisite "knowledges", it is imperative and critical that they understand the inter-relationships between these knowledge constructs in order to successfully integrate ICT into their practice. The inter-relationships are defined as the 'knowledges' that are related to content pedagogy (teaching strategies of specific subject content), technology pedagogy (affordances of specific technology to enhance specific subject learning) and technology content (specific ICT to address specific subject-matter learning). To transform teaching and learning practices in our schools, we need to make a concerted effort to change teachers' beliefs and pedagogical practices through 
dedicated and focussed professional re-training initiatives. Failing to use technology effectively to enhance learning will result in our $21^{\text {st }}$ century learners losing confidence and interest in our anachronistic methods of teaching. This consequence would perpetuate the argument that the educational value of ICT in classrooms is exaggerated (CUBAN, 2001).

Third, the current South African scripted and mandated curriculum favours teachers' existing practices that are defined by the simple act of transmission of knowledge as opposed to pedagogy being a complex science of teaching. Taylor et al. (2019) argue that in the South African context a scripted curriculum improves teaching practice because it eliminates the burden of lesson preparation and saves teachers time. In contrast, Darling-Hammond (2010) posits that teachers' inability to make decisions, without a scripted curriculum, is exactly a consequence of their "preparation" or lack of preparation. Pedagogy should be understood as being a "problematic" thinking process when teachers have to make informed decisions about their classroom practice. Pedagogical practice involves the negotiation of "multiple decision points" in the classroom context by both teacher and learner (LOUHGRAN, 2013). A scripted curriculum that informs teachers "what to teach, when to teach and how to teach" undermines teacher autonomy and their professional expertise (MILNER, 2013). In essence, a scripted curriculum has a debilitating effect on teachers' innovative and creative practices. The overly-ambitious curricula and prepared curriculum manuals do not bode well for teacher creativity, innovation and technology integration.

Even though teachers (in this study) are using technology as a means to facilitate the demands of a scripted mandated curriculum, they are denied individuality and originality in lesson planning. Allowing teachers' own initiative to plan and prepare their lessons based on sound instructional design theory principles, for example, Gagne's Nine Events of Learning (GAGNE, 1981) may enhance not only the effective pedagogical use of technology but also the professional judgement of teachers as active, reasoning decision-makers that guide the teaching-learning. This would promote a coexisting relationship in which "teaching influences learning" and by the same token "learning influences teaching".

\section{Conclusion}

This study confirms the extant empirical findings that teachers are using technology as a tool to support their traditional methods of teaching. The majority of teachers in this study merely enhanced their traditional mode of curriculum delivery, which is not surprising as the extant literature informs us that teachers struggle with integrating ICT into their practice. In search of "what is good here 
(LIGHTFOOT, 1986)?" we recognise teachers' exploration with technology and the innovative ways they try to present curriculum content to learners. Good schools are characterised by having change agents with 'voice and vision' and motivated to challenge the way they teach (p. 24). In the current study, teachers are changing the educational space through their creative use of technology. However, teachers' panoptic understanding of the raison d'etre of technology in their classrooms should include the affordance it offers to enhance learning and teaching. Though technology enhanced new ways to present curriculum content, when viewed through a pedagogical lens, these innovative teaching strategies merely cloaked existing teaching practice as pedagogical innovation.

Teachers believed that their current teaching practice, characterised by the simple act of transmission of content, is pedagogical change. It would seem as though the espoused beliefs (theory-of-action) that teachers hold about pedagogy is incongruent with their actual classroom practice (theory-in-use). There seems to be an anomaly of what teachers perceive as pedagogy and what actually transpires in their classroom practice (ARGYRIS; SCHÖN, 1974), as they cannot discern between teaching and the complex science of pedagogy. This may be attributed to the notion of "apprenticeship of observation". The lived experiences of pre-service teachers must be influenced by understanding, observing and experiencing pedagogical practice. The consequence of being deprived of such experiences seems to have resulted in teachers teaching "the way they have been taught".

The existence of small pockets of excellence illustrate that some teachers are exploring with the affordances technology brings to their pedagogical practices. The goodness here as propounded by the notion of portraiture (LIGHTFOOT, 1986) is that technology enhanced pedagogical changes are emerging, albeit at very slow pace.

\section{End Note}

The South African post-apartheid government of 1994 inherited one of the most unequal educational systems in the world. The apartheid era focused on Christian National Education (CNE) as its central tenet. Post-apartheid South Africa has a complicated history defining its national curriculum innovations. In the short space of its existence in a democratic era since 1994, it has undergone four curriculum iterations. The post-apartheid era (post 1994) saw four successive curriculum changes. First was Curriculum 2005 (C2005), a progressive model of Education based on the principles of outcome-based Education. A paradigm shift to a learner-centred approach with the teacher as facilitator. C2005 was short-lived and barely five years later, was followed through with the National Curriculum 
Statement (NCS) and then the Revised National Curriculum Statement (RNCS). The current Curriculum and Policy Statement (CAPS) is active in all schools. It is sad, however, that all curriculum changes showed no signs of cohesion with the national e-Education policy that mandates the integration of ICT in schools.

South Africa inherited a skewed Education system. The post-1994 South African government created a single national department of Education out of 19 racially, ethnically, and regionally divided "departments of Education". However, manifest inequalities between schools persist. Schools are categorised according to public schools (government subsidised according to a socio-economic tiered structure) or independent schools (minimal or no funding). Public schools are either primary (grade 0 to grade 7) or secondary (grade 8-12). Most public schools are in residential suburbs. Independent schools prefer to exist as comprehensive private schools (grade 0 to grade 12). However, there are still huge socio-economic differences between public schools due to the apartheid legacy. Pre-apartheid schools that catered for uniquely "white" learners have the entire infrastructure (laboratory facilities, technology, classrooms, sports fields, parental involvement) of well-established schools. These schools are called ex-Model C schools and have a pre-dominantly "white" learner population in "white" suburbs and continue to thrive under these supportive conditions. Whilst "township schools" are schools that exist in predominantly "black" communities with all black learners; these schools are socio-economically challenged and continue to struggle with the inherited poor infrastructure, classrooms and non-existent libraries, technology and sports-fields. 


\section{Uma janela para as práticas de TIC dos professores: discernimento entre o ensino e a complexa ciência da pedagogia}

\section{Resumo}

Usando a noção de Loughran sobre a complexidade do ensino, este estudo se propôs a explorar como os professores usavam a tecnologia da informação e comunicação (TIC) em suas práticas em sala de aula. O estudo é baseado em métodos de pesquisa qualitativa. A captura de dados incluiu uma mistura de entrevistas semiestruturadas, observações e análise de documentos. Os dados foram analisados usando métodos de análise de conteúdo. Os resultados foram quádruplos. Primeiro, pequenos grupos de professores inovadores mudaram sua pedagogia. Segundo, as crenças dos professores sugerem uma compreensão (errônea) de seu ensino induzido pelas TIC, que eles perceberam como pedagogia modificada, mas, na realidade, apenas mudaram seu modo de repassar o currículo. Terceiro, a maioria dos professores parecia reposicionar sua prática, usando a tecnologia para facilitar as demandas de um currículo com roteiro, simplesmente mudando sua forma de ensinar. Quarto, a aprendizagem da observação de professores é perpetuada ainda mais por meio de treinamento em serviço que não promove mudanças pedagógicas experienciais.

Palavras-chave: TIC. Pedagogia. Ensino. Aprendizagem experimental. Agentes de mudança.

\section{Una ventana a las prácticas TIC de los docentes: discernimiento entre la enseñanza y la compleja ciencia de la pedagogía.}

\section{Resumen}

Utilizando la noción de Loughran de la complejidad de la enseñanza, este estudio se propuso explorar cómo los maestros usaban la tecnología de la información y la comunicación (TIC) en sus prácticas en el aula. El estudio se basa en métodos de investigación cualitativa. La captura de datos incluyó una mezcla de entrevistas semiestructuradas, observaciones y análisis de documentos. Los datos se analizaron utilizando métodos de análisis de contenido. Los resultados fueron cuádruples. Primero, pequeños grupos de maestros innovadores cambiaron su pedagogía. En segundo lugar, las creencias de los docentes sugieren una comprensión (errónea) sobre su enseñanza inducida por las TIC, que percibieron como pedagogía modificada, pero en realidad solo cambió su modo de entrega del plan de estudios. En tercer lugar, la mayoría de los maestros parecian reposicionar su práctica utilizando tecnología para facilitar las demandas de un currículum con guión, simplemente cambiando su práctica docente. Cuarto, el aprendizaje de observación de los docentes se perpetúa aún más a través de la capacitación en el servicio que no promueve el cambio pedagógico experiencial.

Palabras clave: TIC. Pedagogía. Enseñanza. Aprendizaje experimental. Agentes de cambio. 


\section{References}

ARGYRIS, C.; SCHÖN, D. Theory in practice: increasing professional effectiveness. San Francisco: Jossey-Bass, 1974.

AVIDOV-UNGER, O.; MAGAN-NAGAR, N. Teachers in a changing world: attitudes towards organisational change. Journal of Computers in Education, [s. 1.], v. 1, n. 4, p. 227 - 249, Dec. 2014. https://doi.org/10.1007/s40692-014-0014-x

BEETHAM, H.; SHARPE, R. Rethinking pedagogy for the digital age: designing and delivering e-learning. New York: Routledge, 2007.

BORG, M. The apprenticeship of observation. ELT Journal, London, v. 58, n. 3, p. 274-276, July 2004. https://doi.org/10.1093/elt/58.3.274

CHAI, C.S.; KOH, E.; LIM, C.P. Deepening ICT integration through multilevel design of Technological Pedagogical Content Knowledge. Journal of Computers in Education, [s. 1.], v. 1, p.1-17, 2014. https://doi.org/10.1007/s40692-014-0002-1

CHARMAZ, K. Grounded theory in the 21st Century: applications for advancing social justice studies. In: Norman K. D.; Yvonna E. L. (eds.). Handbook of qualitative research. 3. ed. Thousand Oaks: Sage, 2005. p. 507-535.

CONVERY, A. The pedagogy of the impressed: how teachers become victims of technology vision. Teachers and Teachers, [s. 1.], v. 15, n. 1, p. 25-41, 2009.

CRESWELL, J. W. Mapping the field of mixed methods research. Journal of Mixed Methods Research, Thousand Oaks, v. 3, n. 2, p. 95-108, 2009.

CUBAN, L. Oversold and underused: computers in the classroom. Cambridge: Harvard University Press, 2001.

CZERKAWSKI, B. C.; SCHMIDT, N. ITET: instructional design practices in teacher education. Issues and Trends in Educational Technology, Tucson, v. 6, n. 2, p. 1-3, 2018. https://doi.org/10.2458/azu_itet_v6i2_czerkawski

DARLING-HAMMOND, L. Teacher education and the American future. Journal of Teacher Education, Washington, DC, v. 61, n. 1-2, p. 35-47, 2010. https://doi.org/10.1177/0022487109348024

DAVIS, F. D. Perceived usefulness, perceived ease of use, and user acceptance of information technology. Management and Information Systems Quarterly, Minneapolis, v. 13, n. 3, p. 319-339, 1989. https://doi.org/10.2307/249008 
DENZIN, N.K.; LINCOLN, Y.S. The Sage handbook of qualitative research. Thousand Oaks: Sage, 2005.

FUJII, T. Designing and adapting tasks in lesson planning: a critical process of lesson study. ZDM Mathematics Education, [s. 1.], v. 48, n. 4, p. 411-423, 2016. https://doi.org/10.1007/s11858-016-0770-3

FULLAN, M. Successful school improvement. Buckingham: Open University Press, 1992.

FULLAN, M. G. Why teachers must become change agents. Educational Leadership, Washington, DC, v. 50, n. 6, p. 12-17, Mar. 1993

GAGNE, R. M. et al. Principles of instructional design. 5. ed. Belmont: Wadsworth Publishing, 2004.

GAGNE, R. M. Planning and authoring computer-assisted instruction lessons. Educational Technology, [s. 1.], v. 21, n. 9, p. 17-21, Sep. 1981.

GLESNE, C. Becoming qualitative researchers: an introduction. 3rd ed. Boston: Pearson Education. 2006.

GONZÁLEZ-SANMAMED, M.; SANGRÀ, A.; MUÑOZ-CARRIL, P. We can, we know how: but do we want to? Teaching attitudes towards ICT based on the level of technology integration in schools. Technology, Pedagogy and Education, [s. 1.], v. 26, n. 5, p. 633-647, 2017. https://doi.org/10.1080/1475939X.2017.1313775

HARRISON, C. et al. ImpaCT2: the impact of information and communication technologies on pupil learning and attainment. London: DIES, 2002. (ICT in schools research and evaluation series, v. 7).

HERRERA, M.; FERNANDEZ, D.; SEGUEL, R. Percepción de los profesores sobre integración de TIC en las prácticas de enseñanza en relación a los marcos normativos para la profesión docente en Chile. Ensaio: Avaliação e Políticas Públicas em Educação, Rio de Janeiro, v. 26, n. 98, p. 163-184, jan./mar. 2018. https://doi.org/10.1590/s0104-40362017002501119

HOWARD, S. K.; MATON, K. Theorising knowledge practices: a missing piece of the educational technology puzzle. Research in Learning Technology, London, v. 19, n. 3, p. 191-206, Nov. 2011. 
HOWARD, S. K.; CHAN, A.; CAPUTI, P. More than beliefs: subject areas teachers' integration of laptops in secondary teaching. British Journal of Educational Technology, London, v. 46, n. 2, p. 360-369, Mar.2015. https://doi.org/10.1111/bjet.12139

KEARNEY, M. et al. Viewing mobile learning from a pedagogical perspective. Research in Learning Technology, Bicester, v. 20, n. 1, p. 1-17, 2012. https://doi.org/10.3402/rlt.v20i0.14406

KOEHLER, M. J.; MISHRA, P. What is technological pedagogical content knowledge? Contemporary Issues in Technology and Teacher Education, [s. 1.], v. 9, n. 1, p. 60-70, 2009.

LIGHTFOOT, S. L. On goodness in schools: themes of empowerment. Peabody Journal of Education, [s. 1.], v. 63, n. 3, p. 9-28, Spring 1986.

LOUGHRAN, J. Pedagogy: making sense of the complex relationship between teaching and learning. Curriculum Inquiry, Toronto, v. 43, n. 1, p. 118-141, Jan. 2013. https://doi.org/10.1111/curi.12003

McLAUGHLIN, M. Listening and learning from the field: tales of policy implementation and situated practice. In: LIEBERMAN, A. (ed.). The roots of educational change. Dordrecht: Springer, 2005. p. 70-84.

MARCOVITZ, D.; JANISZEWSKI, N. Technology, models, and 21st-century learning: How models, standards, and theories make learning powerful. $I n$ : SOCIETY FOR INFORMATION TECHNOLOGY \& TEACHER EDUCATION INTERNATIONAL CONFERENCE, 2015., Chesapeake, VA. Proceedings[...]. Chesapeake, VA: Association for the Advancement of Computing in Education, 2015. p. 1227-1232.

MARCINKIEWICZ, H. R.; WELLIVER, P. W. Procedures for assessing teachers' computer use based on instructional transformation. In: CONVENTION OF THE ASSOCIATION FOR EDUCATIONAL COMMUNICATIONS AND TECHNOLOGY SPONSORED BY THE RESEARCH AND THEORY DIVISION, 1993, New Orleans, Louisiana. Research and development presentations[...]. New Orleans: Association for Educational ommunications and technology, 1993. p. 678-684.

MILNER, H. R. Scripted and narrowed curriculum reform in urban schools. Urban Education, [s. 1.], v. 49, n. 7, p. 743-749, 2013. https://doi.org/10.1177/0042085914549685 
NG'AMBI, D.; BOZALEK, V. Editorial: Emerging technologies and changing learning/teaching practices. British Journal of Educational Technology, London, v. 44, n. 4, p. 531-535, 2013. https://doi.org/10.1111/bjet.12061

OWSTON, R. Contextual factors that sustain innovative pedagogical practice using technology: an international study. Journal of Educational Change, [s. 1.], v. 8, n. 1, p. 61-77, 2007. https://doi.org/10.1007/s10833-006-9006-6

PADAYACHEE, K. A Snapshot survey of ICT integration in South African schools. South African Computer Journal, [s. 1.], v. 29, n. 2, p. 36-65. 2017. https://doi.org/10.18489/sacj.v29i2.463

PUENTEDURA, R. R. SAMR and TPCK: intro to advanced practice. Available from: http://hippasus.com/resources/sweden2010/SAMR_TPCK_ IntroToAdvancedPractice.pdf. 2009. Access o 2019 Feb. 9.

RIEBER, L. P.; WELLIVER, P. W. Infusing educational technology into mainstream educational computing. International Journal of Instructional Media, Farmigdale, n. 16, p. 21-32, 1989

RIEL, M.; BECKER, H. The beliefs, practices, and computer use of teacher leaders. In: AMERICAN EDUCATIONAL RESEARCH ASSOCIATION CONFERENCE, 2000, New Orleans, Luisiania. Available from: https://www.researchgate.net/publication/237469096_The_Beliefs_Practices and_Computer_Use_of_Teacher_Leaders1. Access in: 2019 March 30.

SHARPLES, M. et al. Innovating pedagogy, 2014: exploring new forms of teaching, learning and assessment, to guide educators and policy makers. Milton Keynes: Open University, 2014. (Open university innovation report, v. 3).

SILVERMAN, D. Doing qualitative research. 2. ed. London: Sage, 2006.

SOSA, O. G.; MANZUOLI, C. H. Models for the pedagogical integration of information and communication technologies: a literature review. Ensaio: Avaliação e Politicas Públicas em Educação, Rio de Janeiro, v. 27, n. 102, p. 1-16, jan./mar. 2019. https://doi.org/10.1590/s0104-40362018002701720

SOUTH AFRICA. DEPARTMENT OF EDUCATION. Guidelines for teacher training and professional development in ICT. Pretoria: Gvernment Printing Works, 2007.

SOUTH AFRICA. DEPARTMENT OF EDUCATION. White paper on e-education. Pretoria: Gvernment Printing Works, 2004. 
STAKE, R. E. Qualitative case studies. In: DENZIN, N. K.; LINCOLN, Y. S. (eds.). The Sage handbook of qualitative research. Thousand Oaks: Sage, 2005. p. 443-466.

TAYLOR, S. et al. Improving early grade reading in South Africa: 3ie Grantee Final Report. New Delhi: International Initiative for Impact Evaluation, 2019.

VANDEYAR, T. Practice as policy in ICT for education: catalysing communities of practice in education in South Africa. Technology in Society, [s. 1.], v. 35, n. 4, p. 248-257, Nov. 2013. https://doi.org/10.1016/j.techsoc.2013.10.002

VANDEYAR, T. Policy intermediaries and the reform of e-Education in South Africa. British Journal of Educational Technology, London, v. 46, n. 2, p. 344-359, Jan. 2015. https://doi.org/10.1111/bjet.12130

VANDEYAR, T. The appropriation of education policy on information and communication technology in South African schools. 2010. Thesis (PhD) University of Pretoria, 2010.

WANG, L.; ERTMER, P.A.; NEWBY, T.J. Increasing preservice teachers' self-efficacy beliefs for technology Integration. Journal of Research on Technology in Education, [s. 1.], v. 36, n. 3, p. 231-250, Mar. 2004. https://doi.org/10.1080/15391523.2004.10782414

WEBB, M. E. Pedagogy wtith ICT. In: Leask, M.; Pachler, N. (eds.). Learning to teach using ICT in the secondary school: a companion to school experience. 3. ed. London: Routledge, 2014. p. 67-83.

YANG, H. D.; YOO, Y. It's all about attitude: revisiting the technology acceptance model. Decision Support Systems, Amsterdam, v. 38, n. 1, p. 19-31, Oct. 2003. https://doi.org/10.1016/S0167-9236(03)00062-9

YOUSAFZAI, S. Y.; FOXALL, G. R.; PALLISTER, J. G. Technology acceptance: a meta-analysis of the TAM: Part 1. Journal of Modelling in Management, [s. 1.], v. 2, n. 3, p. 251-280, Nov. 2007. https://doi.org/10.1108/17465660710834453 


\section{Information about author}

Thirusellvan Vandeyar: PhD in Computer Integrated Education. Senior Lecturer in the Department of Science, Mathematics, and Technology Education of University of Pretoria. Thirusellvan teaches in the Post Graduate Certificate of Education and honours programmes. He was the recipient of the Laureate Award for Teaching Excellence and Innovation of the University of Pretoria in 2018.Contact: thiru.vandeyar@up.ac.za

iD https://orcid.org/0000-0002-5542-3460 